\title{
Burning wet wood: varieties of non-recognition in energy transitions
}

\author{
Jari Lyytimäki ${ }^{1} \mathbb{0}$
}

Received: 30 November 2018 / Accepted: 20 April 2019 / Published online: 27 April 2019

(c) The Author(s) 2019

\begin{abstract}
One of the most widely accepted rule of thumb of bioenergy production has been that burning wet wood should be avoided. This advice has guided the development of harvesting, logistics and combustion of wood chips. However, experimentations in Finland have challenged this approach by showing that it may be possible to considerably improve the energy efficiency of heat and power plants by burning the wood chips as soon as possible after harvesting them from boreal forests. The high energy content of fresh wood has been known for a long time, but this knowledge has not been widely acknowledged as the guiding principle in the development of the energy use of wood chips. This study analyses public (non)debate of wood chip burning in Finland based on conceptualisations of non-recognition and discusses the implications of knowledge use and non-use for sustainable energy transitions. It is concluded that various forms of non-recognition can significantly hinder the development and implementation of more sustainable energy solutions. The importance of the varieties of ignorance and their societal consequences should not be forgotten from the sustainability transition studies.
\end{abstract}

\section{Graphical abstract}

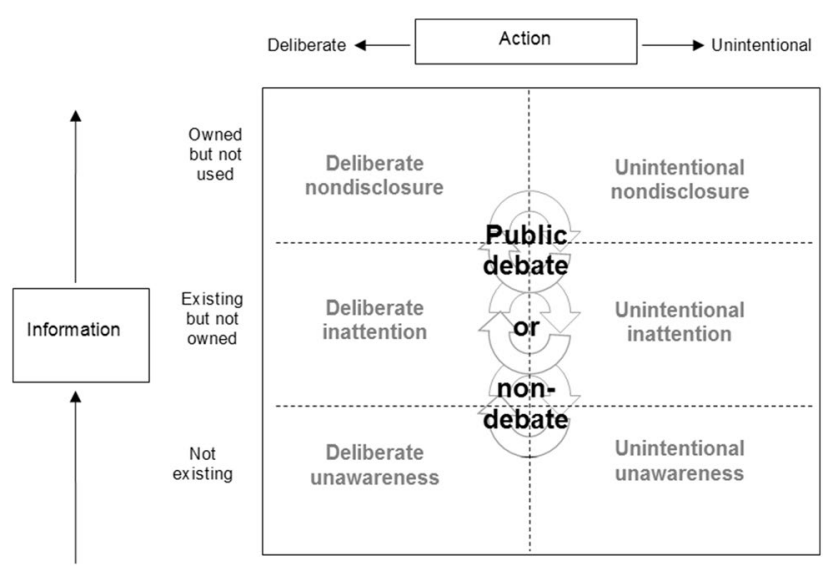

Keywords Combustion $\cdot$ Energy policy $\cdot$ Transition $\cdot$ Knowledge utilisation $\cdot$ Renewable energy $\cdot$ Sustainable development $\cdot$ Wood chips

\section{Introduction}

"It's true! Fresh wood burns better than dry wood".

(Heikkinen 2018, p. 35).

Jari Lyytimäki

jari.lyytimaki@ymparisto.fi

1 Finnish Environment Institute, Latokartanonkaari 11, 00790 Helsinki, Finland
A feature story published by a widely read Finnish magazine challenged the commonly accepted view that firewood should be as dry as possible when burned. Despite 
the title creating an impression that all fresh wood burns better than dry wood, the story actually only focused on wood chips burned in large combustion plants. It argued that about $10-20 \%$ more energy can be obtained from burning fresh wood chips. This storyline strongly suggested that old lessons about the importance of using only dry wood chips as an energy source should be put aside. Some uncertainties and lack of comprehensive knowledge over the issue were noted. After all, the surprising results leading to positive expectations about possibilities to improve energy efficiency were sparked by results from the test burning of fresh chips in just one facility. However, the story also emphasised that the test results are supported by scientifically plausible calculations of energy contents and the best current theoretical understanding of the combustion process.

If the expectations are proven true, they may have considerable implications on the national energy system. Even if not proven true, such publicly presented expectations can play a role in societal debates since they can be used to strengthen and legitimise or weaken and destabilise claims related to energy policy. Such discursive acts can have considerable impact on energy policy, since media, public and policy agendas are closely intertwined (Fischer 2003; Skjølsvold 2012; Anderson et al. 2017). Policy priorities of renewable energy are influenced by public opinion that is influenced by media contents that, in turn, are partly shaped by policy priorities.

The replacement of fossil fuels with renewable energy sources, bioenergy in particular, has been one of the key targets of the Finnish energy policy (Huttunen 2017). Finland is a country of 5.6 million inhabitants and about 0.6 million forest owners. Forest-based biomass is the most important renewable energy source in Finland with a share of over a quarter of all energy consumption. The share of wood chips of all solid wood fuel consumption in heating and power plants is over a third (LUKE 2018a). Largely due to abundant forest resources and the importance of the forest sector in the Finnish economy, the energy use of wood has been widely accepted, contrary to many other countries (Fytili and Zabaniotou 2017). Two-thirds (66\%) of Finns want to increase and only $8 \%$ want to decrease the share of bioenergy in energy production (Energiateollisuus 2017). Forest energy mainly comprising of by-products of the pulp industry, small wood and logging residues has been favoured by the key energy policy actors as an environmentally friendly domestic energy source with considerable employment opportunities. In particular, forest-based energy is an important source of revenues for many rural areas suffering from high unemployment. In rural areas, firewood and wood chips are commonly used for heating. In urban areas, wood is commonly used as a secondary heat source for detached houses. Small-scale wood burning is also culturally important. For example, almost all of the 0.5 million summer cottages of the country have traditional saunas heated with wood.

Wood chips are widely used in the heating of agricultural farms, greenhouses and industrial facilities, even though most of the chips are burned in heat and power plants of towns and cities. Wood chips originate mainly from precommercial thinning operations that are publicly subsidised because of silvicultural reasons. Thinning enhances the growth of remaining trees and enables future commercial wood harvesting. Small- and medium-sized enterprises and co-operatives have an important role in operating small- and medium-size energy plants (Kuitto 2005; Peltola 2011). The energy use of forest chips is also publicly subsidised in order to improve their competitiveness. The use of wood chips started in 1950s and increased as a result of oil crisis in the late 1970s. Changes in prices of competing fuels decreased the use in the late 1980s, but the use increased again in 1990s with growing interest towards bioenergy (Hakkila et al. 2001). The increase in the 2000s is also partly explained by the public subsidies for bioenergy and the supply and pricing of competing fuels. The supply of wood chips has also been influenced by the development of forest harvesting technologies and logistics. Recently, wood chips have lost some of their competitiveness in combined heat and power plants.

Partly due to intensive forest management activities, the annual growth of trees in Finnish forests has clearly surpassed the volume of logging over the past decades (Fig. 1). Despite this, the increasing use of wood has recently raised public criticism because of carbon dioxide emissions from energy production, fears for the sufficiency of wood resources, biodiversity effects in forest ecosystems and other harmful environmental effects. In particular, negative environmental impacts of the removal of tree stumps for wood chips production have received critical media attention (Kangas et al. 2018). Concerns have been increasingly voiced about a decrease in forest carbon dioxide sinks as a result of increased wood harvesting (Soimakallio 2017). An increasing demand of biomaterials and recent massive investments in pulp production have placed more pressure on the sustainable use of forest resources and have highlighted the need to improve energy and material efficiency.

Overall, an improvement in the energy efficiency of wood chip burning could provide a win-win solution for the energy and climate policies. It provides an opportunity to reduce the need for wood chips which automatically reduces all harmful environmental impacts, at least if no major rebound effects are assumed (Gillingham et al. 2016). Alternatively, it allows the increased use of wood materials for other purposes. Increased energy efficiency can also decrease the need to transport great amounts of wood from the forest areas to the energy plants. Furthermore, a more efficient and carefully controlled burning 

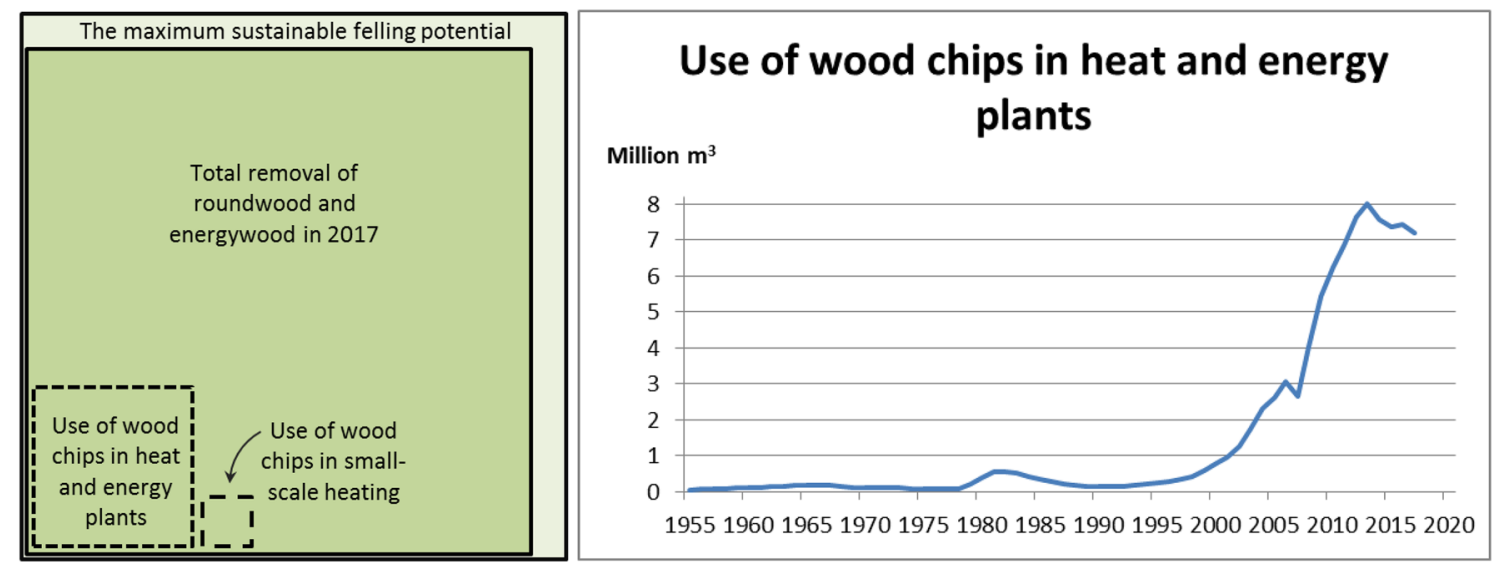

Fig. 1 Total forest use in 2017 (left panel) and the long-term development of the energy use of wood chips in Finland (right panel) (Hakkila et al. 2001; Hakkila 2005; LUKE 2018a, b)

process is likely to decrease emissions that are harmful to the human health and the environment.

Such a variety of expected benefits together with the societal prominence of bioenergy in Finland makes it reasonable to assume that there would be an intensive debate over the energy efficiency of wood chip burning. However, this is not the case. This study focuses on the public debate on the energy efficiency of wood chip burning. The aim is to analyse various reasons why potentially relevant science-based knowledge may remain non-recognised in public debates and how this absence of information may forestall the diffusion of innovation.

The context of the study can be characterised as a mature energy production regime with established actor positions and knowledge claims (Peltola 2011; Kivimaa and Mickwitz 2011). Energy transition studies have widely addressed the importance of new information and innovations challenging the existing conventions and regimes (Geels et al. 2017). In particular, ample scholarly attention has been directed to find out the reasons why certain issues become prioritised by policy makers or energy entrepreneurs (e.g. Nygrén et al. 2015; Duić 2015). Some studies have focused on the visibility of renewable energy in media agendas (e.g. Skjølsvold 2012). Less attention has been paid to the absence of information, unawareness and non-knowledge. This study starts from the basic assumption of ignorance studies: there exists a variety of forms of absence of information with different societal dynamics (Gross and McGoey 2015). The question is not necessarily about the simple symmetric relation between the existence and non-existence of knowledge, but about the different reasons and complicated societal consequences of not knowing.

\section{Materials and methods}

\section{Study design and data sources}

An interpretive case study design is adopted here because it is well suited to analyse the construction of meaning embedded in a specific temporal and spatial context (Flyvbjerg 2006; Astbury and Bell 2018). The empirical data for this study originate from public representations in various media arenas, including newspapers, magazines, online news and online and social media discussions. Media are an interlocutor between the spheres of science and policy, public and private and formal and informal communication. Therefore, media contents can provide an important source of data for applied energy analysis (Fischer 2003; Skjølsvold 2012; Kangas et al. 2018). The ability of the media to make an impact varies between different issues and contexts. Here, it is assumed that the media play an especially influential role when there is asymmetric distribution of knowledge or disagreement between different actors. In these cases, the media can make a difference by setting an agenda that highlights or omits certain issues, as well as by framing certain measures as reasonable and by dismissing others (Downs 1972; Entman 2007).

The data focus on news media contents and other public debates on burning fresh wood chips in national, regional and local media in Finland. Newspapers were the main data source. Newspapers have been widely read, and the societal role of high-quality newspapers is still relatively strong in Finland (Harrie 2018). Finland has a strong national public service broadcasting company along with 
commercial television and radio. Overall, the communication system of Finland can be labelled as democratic corporatist (Hallin and Mancini 2004), characterised by early development and broad diffusion of mass media, a high degree of professionalisation and self-regulation of media and independence from political groups.

A wide variety of data sources were utilised in order to gain a comprehensive picture of the debate. Data sources were screened through online Google searches, searches from the ePress database containing full access to about 200 national, regional and local newspapers and searches from the web portal of the National Broadcasting Company (YLE). The online archives of two prominent newspapers were screened separately. These included the largest national newspaper, "Helsingin Sanomat", and "Maaseudun Tulevaisuus", a widely read newspaper focusing on rural issues, agriculture and forestry. Both newspapers can be characterised as high-quality newspapers.

All types of publicly presented journalistic material, as well as columns, op-eds and letters to the editor and other commentaries, were included. All relevant hits were included regardless of their publication time. Because of differences in databases, the combinations of search strings varied somewhat but included at least the following terms: "chips" (in Finnish: hake), "wood chips" (puuhake), "fresh" (tuore), "wet" (märkä) and "burning" (poltto). The initial searches generated a high number of hits. Together with earlier research, this suggests that wood chips are a relatively widely debated topic in Finnish energy policy (Kuitto 2005; Peltola 2011; Kivimaa and Mickwitz 2011). Items only mentioning the burning of fresh wood chips in passing were not included for this study, but they were manually screened for possible references pointing to potential additional news items related to the debate. Table 1 presents the items included in this study.

A qualitative content analysis approach was used to interrogate the data (Krippendorff 2004). The analysis focused on both manifest and latent contents. Manifest content refers here to the factual claims, value positions and other properties directly expressed through wordings or visualisations. Latent contents refer to between-the-lines type of information, such as indirectly presented claims, visual cues, omissions of certain viewpoints or data and background information required for the understanding of the message (Neuendorf 2017). Identification of such "hidden meanings" involves subjective interpretation, and assumptions made taking into account the specific context of the studied phenomena. In order to reduce potential bias caused by the

Table 1 Materials for the study

\begin{tabular}{|c|c|c|}
\hline Type & Time & Title \\
\hline Newspaper "Maaseudun Tulevaisuus" & 15 February 2000 & Fresh chips provide heat efficiently \\
\hline $\begin{array}{l}\text { National Broadcasting Company "YLE" (regional } \\
\text { office) }\end{array}$ & 17 January 2012 & Chip burner invention makes water combustible \\
\hline National Broadcasting Company "YLE" & 16 October 2013 & Fresh wood warms better than dry wood \\
\hline Professional magazine "Energiauutiset" & 13 June 2016 & Frontrunners are brave \\
\hline Regional newspaper "Ilkka" & 22 September 2016 & Chemists will verify the theory \\
\hline Newspaper "Maaseudun Tulevaisuus" & 23 December 2016 & $\begin{array}{l}\text { Beliefs turned around: Fresh wood burns better than } \\
\text { dry wood }\end{array}$ \\
\hline $\begin{array}{l}\text { Online debate, professional magazine "Metsälehti", } \\
\text { discussion thread with } 39 \text { comments }\end{array}$ & 27 December 2016 (start date) & Burning of felling-fresh wood \\
\hline Newspaper "Maaseudun Tulevaisuus" & 14 June 2017 & $\begin{array}{l}\text { Even better experiences from burning fresh chips: "We } \\
\text { have been amazed" }\end{array}$ \\
\hline $\begin{array}{l}\text { Several regional newspapers: "Etelä-Saimaa", "Kou- } \\
\text { volan Sanomat", "Itä-Savo", "Kymen Sanomat", } \\
\text { "Länsi-Savo" }\end{array}$ & 22 January 2017 & The dominance of dry wood is cracking \\
\hline Newspaper "Maaseudun Tulevaisuus" & 14 February 2017 & $\begin{array}{l}\text { Fresh wood burns happily in a growing number of } \\
\text { power plants }\end{array}$ \\
\hline National Broadcasting Company "YLE" & 17 February 2017 & $\begin{array}{l}\text { Slip-up in a power plant produced a surprising discov- } \\
\text { ery: It's not worthwhile burning dry wood }\end{array}$ \\
\hline $\begin{array}{l}\text { Online debate, "Suomi24" discussion thread with } 10 \\
\text { comments }\end{array}$ & 17 February 2017 (start date) & Drying wood is a mug's game \\
\hline $\begin{array}{l}\text { Online debate, "Suomi24" discussion thread with } 19 \\
\text { comments }\end{array}$ & 17 February 2017 (start date) & Fresh wood burns better than dry \\
\hline Newspaper "Maaseudun Tulevaisuus" & 24 November 2017 & $\begin{array}{l}\text { The research confirms: Fresh wood burns more effi- } \\
\text { ciently than dry }\end{array}$ \\
\hline Magazine "Suomen Kuvalehti” & 12 January 2018 & It's true! Fresh wood burns better than dry wood \\
\hline
\end{tabular}


subjective judgements inherent to the qualitative approach (Alasuutari 1995), the material was analysed through multiple rounds of interpretation, guided by the insights from the literature of non-recognition and other literature. Conceptual framework that guided the analysis is presented in the next section.

\section{Conceptual background: types of non-recognition}

This study analyses the public discussion of wood chips based on conceptualisations of non-recognition developed by ignorance studies and models explaining the dynamics of media coverage (Gross and McGoey 2015; Hansen and Cox 2015). The dynamics of media coverage have been widely studied. Empirical studies have increasingly used longitudinal data from newspapers and other data sources to describe the ups and downs of attention given to various societal issues such as climate change (Schmidt et al. 2013). Models aiming to explain the dynamics have mainly focused on the reasons explaining the rise of certain issue into public agenda (Downs 1972; Carvalho and Burgess 2005; Mazur 2006; Holt and Barkemeyer 2012). Less attention has been paid to the reasons leading to the decline of the media interest or the potential reasons for the non-recognition by the media.

Non-recognition refers to various types of lack of information, not knowing and ignorance (Smithson1989; Proctor and Schiebinger 2008; Gross 2010; Gross and McGoey 2015). It has been studied from various perspectives ranging from theoretical work aiming to build a comprehensive understanding of the phenomenon to practical applications of the effects of non-recognition in organisations, policy processes or individual decisions in everyday life (e.g. Kutsch and Hall 2010; Owens 2017). This study takes a typology of six types of non-recognition as a starting point to organise the discussion. The types are developed from earlier research (Gross 2010; Lyytimäki et al. 2011; Lyytimäki and Assmuth 2017). The typology aims to provide a widely applicable framework to describe different motivations for nonrecognition. It is based on two dimensions: whether or not the information already exists and whether or not the actor is willing to acquire the potentially missing information or communicate it to others (Fig. 2). The resulting six types of non-recognition are dynamic and partially overlapping.

The framework highlights that the state of not knowing can be deliberate or unintentional. First, deliberate nondisclosure occurs when an actor possessing the information restricts communication or refrains from communication altogether. The motivation may be the perceived need to avoid unwanted consequences of information sharing, such as securing commercial or political interests, avoiding the creation of misunderstandings or unnecessary worries among the audience (Mazur 2004; Owens 2017). Deliberate

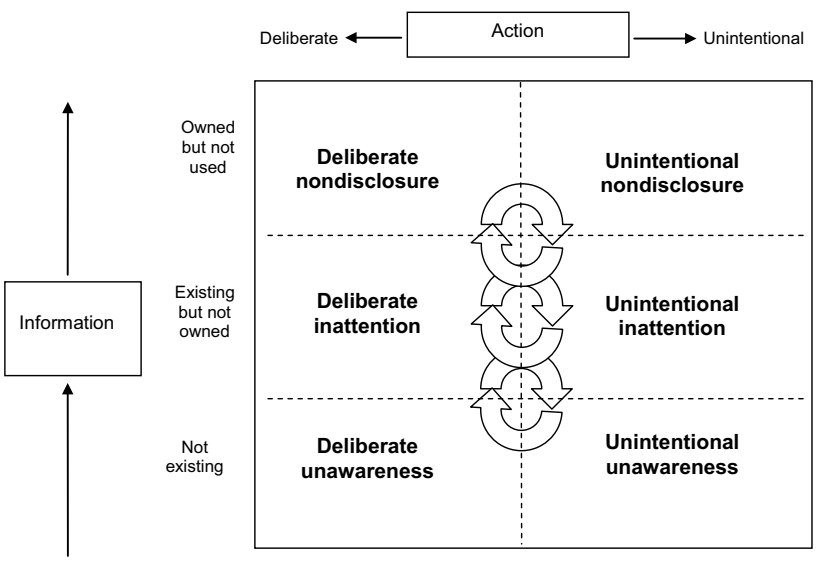

Fig. 2 Schematic typology of forms of not knowing and their dynamic interaction (based on Lyytimäki et al. 2011; Lyytimäki and Assmuth 2017)

nondisclosure can be passive non-communication or an active dismissal of information requests.

Second, deliberate inattention occurs when an actor deliberately chooses not to acquire missing information that already exists. The concept closely relates to what has been labelled as informed ignorance (Fernler 2015). The information may be considered to be a completely off-topic, or acquiring and understanding it may be perceived as being too difficult or costly in relation to the potential benefits. Examples of such information include a scientific article that is freely available but difficult to find or a relevant scientific article behind a paywall, making the information too costly. Deliberate inattention may also be because of legal or moral obligations, such as sectorial boundaries between authorities or taboos reflecting cautionary restrictions placed on action based on what is deemed to be inappropriate (Kutsch and Hall 2010; Fernler 2015).

Third, deliberate unawareness describes a process in which an actor acknowledges that information about a certain issue is missing but considers that generating new knowledge is not necessary or possible and hence considers the state of unawareness as acceptable. The issue may be perceived as being not interesting or unimportant, and therefore, it makes no sense to invest resources in knowledge generation. Deliberate unawareness may also be a strategy aimed at avoiding producing potentially unpleasant new information, such as "inconvenient truths" about environmental degradation (Rayner 2012). Deliberate unawareness can prevail under false premises, when an actor wrongly assumes that all relevant information needed to assess the need for new knowledge is already possessed. This type of unawareness can be seen as one form of wilful ignorance (Perl et al. 2018).

Fourth, unintentional nondisclosure refers to a failure of communication. Such a failure to share information can be 
caused by a lack of resources for active communication or a lack of interest from the potential audience. Disciplinary or organisational borders and dividing lines between societal sectors often lead to unintentional nondisclosure (Mazur 2004). Furthermore, local or lay knowledge can be omitted from expert debates simply because of a lack of appropriate technical vocabulary and capacity to communicate. Likewise, scholarly knowledge often fails to reach lay audiences because it is too technical or because it comes too late to make an impact on the topical debate.

Fifth, unintentional inattention refers to a situation in which potentially relevant knowledge exists but remains unnoticed. Several reasons can lead to unintentional inattention, including personal routines of communication and interaction, heuristics of information acquisition, culturally shaped blind spots, disciplinary boundaries or institutionalised practices of communication and non-communication. Information and communication technology can both forestall unintentional inattention by automatically suggesting relevant information and lead to inattention by creating echo chambers that filter out information received by the individual (Jasny et al. 2018). As noted by Schwarzkopf (2018) from the perspective of organisational ignorance, unintentional inattention can emerge because of an overflow of too much data. Unintentional inattention can also refer to a process in which existing information becomes erased from the memory of an individual or institution.

Sixth, unintentional unawareness refers to a complete lack of any knowledge, also labelled as nescience (Gross 2010). Such unknown unknowns can only be recognised in retrospect. Unintentional unawareness arises from both the dynamics of knowledge generation and limitations in human perception. Issues characterised by unintentional unawareness are outside the scope of human communication, but the retrospective recognition of such unknown unknowns can lead to more active forms of inattention or attention.

\section{News challenging the prevailing wood wisdom}

\section{Overall development of the debate}

The debate over using fresh wood as an energy source has been scattered, and the volume of the news coverage and other public debate has been very low until recent years. The first news story was found from 2000. This item was published by the newspaper "Maaseudun Tulevaisuus" (MT). MT is a widely read national-level newspaper focusing on agriculture and forestry issues. The news item entitled "Fresh chips provide heat efficiently" described how unseasoned chips are burned in a local heat plant also using waste materials as fuel. The relatively high energy content of fresh chips was discussed, but the news item focused more on the potential risks of the emissions from waste incineration and the low profitability of the utilisation of trees for energy production. This news item did not raise any wider debate or follow-up coverage despite the promising - but not reliably verified-results from the burning of fresh chips.

Another case was discussed over a decade later. In 16 October 2013, the National Broadcasting Company (YLE) published a domestic news piece highlighting that "Fresh wood warms better than dry wood", but also casting serious doubts over the issue. The news described how a local energy entrepreneur had unsuccessfully tried to convince energy experts about the feasibility of new combustion technology developed by his firm and capable of burning fresh wood chips with improved energy efficiency. The news reported about a new collaboration with a local energy cooperative aimed at demonstrating the benefits of the technology. However, the news also created sceptical and even comical framings of an innovator aiming to "burn water". It was also mentioned that the details of the invention were kept in secrecy due to commercial interests. Earlier coverage by the regional office of the National Broadcasting Company (17 January 2012) discussing the same case mentioned that even the location of the test facility was kept in secrecy.

A more voluminous debate emerged in 2016 focusing on another case. No reference was made to the earlier cases. A news piece by MT entitled "Beliefs turned around: Fresh wood burns better than dry wood" was published on 23 December 2016. It claimed that energy efficiency can be increased by tens of per cents with new domestic technology designed for the combustion of biomass in large energy plants. It was emphasised that this information is "completely at odds with all prior conceptions" and that it will revolutionise the future energy use of wood. The news story described that the possibilities to improve the energy efficiency were first noticed during the previous winter when a load of fresh chips was accidentally burned in a heat plant. The operators of the facility observed that much more energy was obtained from the fresh chips and that the burning process was especially "clean". The news item emphasised that the issue is being studied by a working group involving several professor-level researchers. Another news piece with essentially the same information was published a little later (17 February 2017) by the National Broadcasting Company. Several regional newspapers also covered the topic (22 January 2017) emphasising that "fresh winter wood has the best heat content".

The existence of prominent spokespersons or organisations advocating an issue is one key precondition for societal salience (Downs 1972). A new kind of public recognition was achieved when a prominent Finnish policy maker, former Commissioner of the European Commission, current Governor of the Bank of Finland, Mr. Olli Rehn gave a 
speech during the opening ceremonies of a new power plant designed to use fresh wood chips, as described, e.g. by the magazine "Energia-Uutiset" (13 June 2016). The participation by a nationally distinguished figure gave some visibility and social credibility to the launch of the new kind of energy technology. However, long-term issue advocates (such as prominent non-governmental organisations) dedicated to keep the issue high in the public and media agenda were missing.

Overall, the news coverage from the late 2016 onwards was characterised by positive and even enthusiastic framings. Under these positive framings, only a few reservations and sceptical views were presented. For example, the regional newspaper "Ilkka" (22 September 2016) highlighted the need to verify the first experiences with more rigorous testing. The representatives of the heat plant responsible for the preliminary tests expressed how they were amazed and how they found it difficult to believe their own good results from test burnings.

Results from new studies become available in late 2017. The newspaper MT (24 November 2017) reported about tests showing that the burning of fresh birch (Betula pubescens, Betula pendula) chips produces $17 \%$ more energy for heating than burning dry chips. Fresh pine (Pinus sylvestris) chips produce $12 \%$ more energy. The news highlighted that, in fact, the facilities designed to use dry wood require a double amount of wood. The energy efficiency of facilities using fresh chips is improved partly because of the advanced heat recovery from fumes. The CEO of the heat plant conducting the tests commented that "The difference is incomprehensible. Logging waste trees dried in piles should not be burned at all". These results were noticed by several other news outlets.

The news coverage generated some online comments featuring more critical and polarised debate, especially in spring 2017. A polarisation of views commonly occurs in online debates (Lyytimäki 2010; Karlsen et al. 2017). In this case, the controversies were partly based on confusions created by poorly justified assumptions and false generalisations resulting partly from the media coverage not discussing the details of the technology. Some comments referred to burning in small-scale fireplaces and stoves, even though the claims of improved energy efficiency were about combustion processes in specifically designed relatively large heat plants. Wet and old wood material was also referred to even though the focus here is strictly on fresh wood chips chopped during wintertime when the growing season is over and when the relative moisture of wood is low. These misunderstandings were soon corrected by the replies of other debaters.

The main topics publicly discussed focused mainly on energy efficiency and left other issues largely untouched. Potential benefits and disadvantages of burning fresh chips are summarised in Table 2. The media coverage focused predominantly on issues directly related to combustion process itself. Other potential benefits and disadvantages of burning fresh chips received only marginal attention even though several different topics have been identified by the research (Autio 2017; Lahti et al. 2016, 2018).

Table 2 Potential benefits and disadvantages of using fresh wood chips and their media coverage

\begin{tabular}{|c|c|}
\hline Benefits & Disadvantages \\
\hline Environmental & Environmental \\
\hline More efficient and clean burning process** & \multirow{2}{*}{$\begin{array}{l}\text { Risk of increased emissions from transportation of heavy } \\
\text { chips }\end{array}$} \\
\hline Avoidance emissions to air during the seasoning process & \\
\hline Avoidance of potential discharges to water from storage & \multirow{3}{*}{$\begin{array}{l}\text { Increased nutrient losses from forests endangering future } \\
\text { growth of trees }\end{array}$} \\
\hline Minimised risk of insect damages & \\
\hline Minimised health risks caused by microbial activity & \\
\hline Economic & Economic \\
\hline \multirow[t]{3}{*}{ Economic gains through improved energy efficiency** } & Investment costs of new burners in heat plants* \\
\hline & Reorganisation of the logistics \\
\hline & Increased transportation costs of heavy chips \\
\hline Decreased storage costs* & Difficulties of pricing fresh chips \\
\hline Easier and more cost-efficient chipping process & \\
\hline Faster turnaround rate of the capital & \\
\hline
\end{tabular}

**Issues often highlighted by the media

*Issues mentioned only occasionally 


\section{Varieties of non-recognition}

As noted by Stocking and Holstein (1993, p. 187), through the lenses of non-recognition and ignorance, we can see knowledge in ways we might not have otherwise-as more or less relevant, or as more or less certain, complete, accurate or unbiased than our assumptions might have allowed us to see. Several types of non-recognition can be discerned from the news and public debate over burning fresh wood chips. Complete lack of media coverage before the millennium and very low level of debate in the early 2000s is noteworthy. It is likely that many of the actors of energy sector faced a state of unintentional inattention at least before the issue gained some salience in late 2016. Burning fresh wood remained a non-issue for actors who had uncritically accepted the rule of thumb of dry wood chips as a preferred energy source also in large-scale combustion. Both experts and other actors may be unwilling or unable to adopt new information that challenges the deeply rooted conceptions, mental models and everyday routines and heuristics (Hukkinen and Huutoniemi 2014). Such routines and conceptions have been purposefully created by information campaigns emphasising the importance of burning only dry wood. Even though these information campaigns have focused on lay people and on the small-scale burning of wood, they have created framings that influence conceptions about all wood burning. Furthermore, the use dry wood chips is accepted as a self-granted premise in guidance documents, practices of wood chip contractors, commercial contracts and standards that define the maximum moisture content of wood chips used in large-scale commercial plants (e.g. Kuitto 2005; Lepistö 2010; VTT 2014).

Despite the lack of news coverage, not all actors were in a state of not knowing. Forest energy potentials-including the possibilities to use logging residues-have been extensively studied in Finland (e.g. Korpilahti 1998; Kuitto 2005; Huttunen 2017; Pöykiö et al. 2018). There also exists the literature that convincingly shows that the energy content of wood is decreased during the seasoning process, ranging from international refereed research to academic thesis and more practice-oriented reports and guidebooks (e.g. Kärkkäinen 2007; Hakonen and Laurila 2011; Routa et al. 2018). However, the international scholarly literature remains largely behind paywalls and it is characterised by technical or theory-loaded language inaccessible to other than a small group of dedicated experts. Hence, the debate has been influenced by unintentional nondisclosure of existing scholarly knowledge. Possible reasons for the nondisclosure include lack of resources and motivation of experts to communicate with larger audience and lack of interest by the journalists and other knowledge brokers.

Deliberate nondisclosure was present as well. As indicated by the news coverage by the National Broadcasting
Company in 2012 and 2013, not all knowledge originating from practical experimentations and commercially based development was publicly shared. The news coverage pointed out that secrecy about technical details of energy invention allowing the burning of fresh chips was deliberately upheld in order to secure potential commercial profits. The inventor of the new technology commented that he "... does not want to open up the detailed process because the whole idea of the invention would be exposed" (National Broadcasting Company 16 October 2013). This lack of openness was one reason that inhibited the wider debate. It also questioned the credibility of the invention and the inventor. Deliberate nondisclosure by the entrepreneur did not allow verification of the claims, but instead lead to comical public framings of a foolish "mad scientist" trying to burn water (Haynes 2003). The risk of being ridiculed is a strong factor preventing participation in public debate (Billig 2005).

As noted by Geiger and Swim (2016), nondisclosure of existing knowledge may indicate a situation where actors are reluctant to share information because they wrongly assume that their peers are more doubtful about the new insights than they actually are. Consequently, a ring of silence preventing the communication may prevail because people are afraid of losing their prestige — or even being ridiculed by their peers. As indicated by the results from this study and the literature of strategic niche management (Schot and Geels 2008), niche-level experimentations can provide protected spaces that allow actors with radical new ideas to challenge the prevailing conceptions. However, system-level changes beyond individual facility are likely to require a more wide public recognition of the limits of current knowledge and long-term experimentation involving co-evolution of technology, user practices and conceptions and regulatory structures.

The emergence of public debate during late 2016 was partially explained by the operation logic of the media emphasising the unexpectedness and violation of norms as one of the key news criteria. The new results from the test burning of fresh chips provided the media with surprising information challenging old conventions and beliefs. Unlike in 2000 and 2012-2013, this time the information was framed as trustworthy, as it was comprised of concrete and openly shared information provided by operators of a heat plant with strong practice-oriented experience and theory-oriented information provided by independent and recognised scholars. Existence of information providers recognised as trustworthy is a key precondition of the rise of an environmental or science-based issue to public agenda (Downs 1972; Mazur 2004; Carvalho and Burgess 2005). Importantly, potential uncertainties and unknown issues subject for further studies were emphasised by the information providers. This suggested the possibility of unintentional inattention or even unintentional unawareness related to burning of fresh 
wood chips. Thus, ignorance was recognised and used to persuade the audience of communication about the importance of the issue and rationality of the activity.

Distribution of the latest science-based information to the early adopters is one prerequisite of energy transitions (Nygrén et al. 2015; Geels et al. 2017). Scientists were given a voice in news coverage, but published peer-reviewed results were not referred in their interviews. News coverage did not provide audiences with direct links to published scientific studies. This was partly because journalistic conventions and presentation formats of popular media favour interview comments over references to the literature. An earlier study has indicated that research results are typically not referred to directly by the media coverage related to sustainability of wood chips originating from tree stubs and roots (Kangas et al. 2018). Another explanation was that high-quality peer-reviewed scientific studies were not yet available. For example, a web page of the research project mentioned by the news did not contain any results from test burning or links publications (TUOHI 2018). Only a short description of the research focusing on the logistics of fresh energy wood was given. Likewise, the press release outlining the final results of the project briefly described the key results without giving links to more detailed data (SeAMK 2018). Such absence of openly available expert and scholarly information may inhibit or delay the diffusion of innovation.

The public debate mostly focused on regional and local news outlets in rural areas or specialised newspapers, magazines and online discussion groups. Thus, it seems that unintentional inattention characterised many of the most influential national-level news outlets, such as the country's most widely read newspaper "Helsingin Sanomat". The volume of the news reporting and other debate returned to a low level after the peak of late 2016 and early 2017. Overall, it can be interpreted that the debate is still at the first phase of the societal issue-attention cycle (Downs 1972). This phase is characterised by some expert-based debate, but a low level of media coverage and lack of awareness by most audiences. Weak signs of the second phase of issue-attention cycle — alarmed discovery and euphoric enthusiasm — were found, but the low overall volume and scattered nature of the media coverage indicate that the topic still remains non-recognised by larger expert audiences interested about renewable energy.

\section{Conclusions}

Theoretical underpinnings and practical consequences of knowledge nonproduction and lack of communication are poorly known, if compared with scholarly understanding related to knowledge production and science communication. Sustainable energy transitions provide one relevant case where explorations of non-recognition are important. Both intentional and unintentional forms of non-recognition may hinder the verification of the feasibility of proposed solutions, technology diffusion and changes in current practices that are needed to induce energy transformations. In short, different types of ignorance can create societal inertia stabilising current regimes.

The case of burning fresh wood chips studied here showed how an issue with potentially considerable implications on energy efficiency and national-level energy policy may remain outside societal spotlights. Despite the temporarily increased public salience resulting from research based on local-level experimentation, no long-lasting major impact on the public agenda could be discerned. Media attention of burning of fresh wood chips still remains on a low level.

The production of new knowledge is an obvious but not always the best way to eradicate unwanted forms of nonrecognition. The case of burning fresh wood chips serves as a reminder of the importance of targeted and clear communication of existing information in order to avoid unintentional inattention. In the current information intensive society recognition, the recovery and re-utilisation of knowledge may be even more important than the production of new information.

Acknowledgements Open access funding provided by Finnish Environment Institute (SYKE). This study was supported by Academy of Finland project "Towards a future oriented 'Energiewende': An anticipatory multi-level approach to the decentralised renewable energy transition" (FutWend) (297748). I thank anonymous referees for insightful comments.

Open Access This article is distributed under the terms of the Creative Commons Attribution 4.0 International License (http://creativeco mmons.org/licenses/by/4.0/), which permits unrestricted use, distribution, and reproduction in any medium, provided you give appropriate credit to the original author(s) and the source, provide a link to the Creative Commons license, and indicate if changes were made.

\section{References}

Alasuutari P (1995) Qualitative method and cultural studies. Sage, London

Anderson B, Böhmelt T, Ward H (2017) Public opinion and environmental policy output: a cross-national analysis of energy policies in Europe. Environ Res Lett 12:114011. https://doi. org/10.1088/1748-9326/aa8f80

Astbury J, Bell S (2018) Assessing and addressing energy vulnerability at the community scale: an interpretive case study. People Place Policy 12(1):29-46. https://doi.org/10.3351/ppp.2018.24358 34443

Autio A (2017) Tuoreen puun polttaminen lämpölaitoksessa. Seinäjoen ammattikorkeakoulu, Seinäjoki

Billig M (2005) Laughter and ridicule: towards a social critique of humour. Sage, London 
Carvalho A, Burgess J (2005) Cultural circuits of climate change in UK broadsheet newspapers, 1985-2003. Risk Anal 25:1457-1469. https://doi.org/10.1111/j.1539-6924.2005.00692.x

Downs A (1972) Up and down with ecology: the 'issue-attention' cycle. Publ Interest 28:38-50

Duić N (2015) Is the success of clean energy guaranteed? Clean Technol Environ Policy 17(8):2093-2100. https://doi.org/10.1007/ s10098-015-0969-y

Energiateollisuus (2017) Suomalaisten energia-asenteet 2017. Energiateollisuus ry \& IROResearch Oy. https://energia.fi/files /2229/Energiateollisuus_-_Energia-asenteet_2017.pdf. Accessed 18 Nov 2018

Entman RM (2007) Framing bias: media in the distribution of power. J Commun 57(1):163-173. https://doi.org/10.111 $1 / \mathrm{j} .1460-2466.2006 .00336 . x$

Fernler K (2015) Informed ignorance and the difficulty of using guidelines in policy processes. Evid Policy 11(2):377-396. https://doi. org/10.1332/174426415X14381763267134

Fischer F (2003) Reframing public policy: discursive politics and deliberative practices. Oxford University Press, Oxford

Flyvbjerg B (2006) Five misunderstandings about case-study research. Qual Inq 12(2):219-245. https://doi.org/10.1177/1077800405 284363

Fytili D, Zabaniotou A (2017) Social acceptance of bioenergy in the context of climate change and sustainability-A review. Curr Opin Green Sustain Chem 8:5-9. https://doi.org/10.1016/j.cogsc .2017.07.006

Geels FW, Sovacool BK, Schwanen T, Sorrell S (2017) The sociotechnical dynamics of low-carbon transitions. Joule 1(3):463-479. https://doi.org/10.1016/j.joule.2017.09.018

Geiger N, Swim JK (2016) Climate of silence: pluralistic ignorance as a barrier to climate change discussion. J Environ Psyc 47:79-90. https://doi.org/10.1016/j.jenvp.2016.05.002

Gillingham K, Rapson D, Wagner G (2016) The rebound effect and energy efficiency policy. Rev Env Econ Policy 10(1):68-88. https ://doi.org/10.1093/reep/rev017

Gross M (2010) Ignorance and surprise: science, society, and ecological design. MIT Press, Cambridge

Gross M, McGoey L (2015) Routledge international handbook of ignorance studies. Routledge, New York

Hakkila P (2005) Metsähakkeen käytön kehittyminen. In: Kuitto P-J (ed) Metsästä biopolttoaineeksi. Tuotannon puoli vuosisataa. FINBIO-Suomen Bioenergiayhdistys ry, Jyväskylä, pp 62-67

Hakkila P, Nousiainen I, Kalaja H (2001) Metsähakkeen käyttö Suomessa. Tilannekatsaus vuodesta 1999. VTT Tiedotteita 2087. Valtion teknillinen tutkimuskeskus, Espoo

Hakonen T, Laurila J (2011) Metsähakkeen kosteuden vaikutus polton ja kaukokuljetuksen kannattavuuteen. Raportteja ja selvityksiä 55 . Seinäjoen ammattikorkeakoulu, Seinäjoki

Hallin DC, Mancini P (2004) Comparing media systems. Cambridge University Press, Cambridge

Hansen A, Cox R (eds) (2015) The Routledge handbook of environment and communication. Routledge, New York

Harrie E (ed) (2018) Newspapers in the Nordic Media Landscape 2017. Nordic Media Trends, vol 14. Nordicom, Göteborg

Haynes R (2003) From alchemy to artificial intelligence: stereotypes of the scientist in western literature. Public Underst Sci 12(3):243253. https://doi.org/10.1177/0963662503123003

Heikkinen S (2018) Väärää tietoa. Suomen Kuvalehti 2/2018, pp 34-39. (12 January 2018)

Holt D, Barkemeyer R (2012) Media coverage of sustainable development issues-attention cycles or punctuated equilibrium? Sustain Dev 20(1):1-17. https://doi.org/10.1002/sd.460

Hukkinen JI, Huutoniemi KI (2014) Heuristics as cognitive tools for pursuing sustainability. In: Huutoniemi K, Tapio P (eds)
Transdisciplinary sustainability studies: a heuristic approach. Routledge, London, pp 177-193

Huttunen R (ed) (2017) Government report on the national energy and climate strategy for 2030. Ministry of Economic Affairs and Employment, Helsinki

Jasny L, Dewey AM, Robertson AG, Yagatich W, Dubin AH, Waggle JM, Fisher DR (2018) Shifting echo chambers in US climate policy networks. PLoS One 13(9):e0203463. https://doi.org/10.1371/ journal.pone. 0203463

Kangas H-L, Lyytimäki J, Saarela S-R, Primmer E (2018) Burning roots: stakeholder arguments and media representations on the sustainability of tree stump extraction in Finland. Biomass Bioenergy 118:65-73. https://doi.org/10.1016/j.biombioe.2018.08.006

Kärkkäinen M (2007) Puun rakenne ja ominaisuudet. Metsäkustannus, Helsinki

Karlsen R, Steen-Johnsen K, Wollebæk D, Enjolras F (2017) Echo chamber and trench warfare dynamics in online debates. Eur $\mathrm{J}$ Commun 32(3):257-273. https://doi.org/10.1177/0267323117 695734

Kivimaa P, Mickwitz P (2011) Public policy as a part of transforming energy systems: framing bioenergy in Finnish energy policy. J Clean Prod 19(16):1812-1821. https://doi.org/10.1016/j.jclep ro.2011.02.004

Korpilahti A (1998) Finnish forest energy systems and $\mathrm{CO}_{2}$ consequences. Biomass Bioenergy 15(4-5):293-297. https://doi. org/10.1016/S0961-9534(98)00037-3

Krippendorff K (2004) Content analysis: an introduction to its methodology, 2nd edn. Sage, Thousand Oaks

Kuitto P-J (ed) (2005) Metsästä biopolttoaineeksi. Tuotannon puoli vuosisataa. FINBIO — Suomen Bioenergiayhdistys ry, Jyväskylä

Kutsch E, Hall M (2010) Deliberate ignorance in project risk management. Int J Project Manag 28(3):245-255. https://doi. org/10.1016/j.ijproman.2009.05.003

Lahti J, Lauhanen R, Kitinoja A (2016) Tuoreen puun polttaminenuusi avaus. In: Junell P, Heikkilä A, Päällysaho S, Saarikoski S (eds) Hyvinvointia ja innovaatioita monialaisesti ja raja-aitoja madaltaen. Seinäjoen Ammattikorkeakoulu, Seinäjoki, pp $451-465$

Lahti J, Lauhanen R, Timonen R, Laasasenaho J, Kitinoja A (2018) Onko tuoreen puun poltosta hyötyä maatilametsänomistajalle? Tuoreen energiarangan hankintalogistiikan ja polton kehittäminen. Suomen Maataloustieteellisen Seuran Tiedote Nro 35: 1-7. https ://journal.fi/smst/article/view/73235. Accessed 18 Nov 2018

Lepistö T (ed) (2010) Laatuhakkeen tuotanto-opas, 2nd edn. EteläPohjanmaan Metsäkeskus, Seinäjoki

LUKE (2018a) Wood in energy generation 2017. Natural Resources Institute Finland. https://stat.luke.fi/en/wood-energy-generation -2017_en. Accessed 18 Nov 2018

LUKE (2018b) E-yearbook of food and natural resource statistics for 2017: statistical facts on agriculture, forestry, fisheries and hunting in Finland. Natural resources and bioeconomy studies 20/2018. Natural Resources Institute Finland. http://stat.luke.fi/sites/defau lt/files/luke-luobio_20_2018.pdf. Accessed 18 Nov 2018

Lyytimäki J (2010) Naurua ilmassa: Koominen vähättely ilmastontutkimusta käsittelevässä verkkokeskustelussa. Kulttuurintutkimus 27(2): $17-29$

Lyytimäki J, Assmuth T (2017) Absent information in integrative environmental and health risk communication. In: Parrott R (ed) Encyclopedia of health and risk message design and processing. Oxford University Press, New York. https://doi.org/10.1093/acref ore/9780190228613.013.534

Lyytimäki J, Assmuth T, Hildén M (2011) Unrecognized, concealed or forgotten - the case of absent information in risk communication. J Risk Res 14(6):757-773. https://doi.org/10.1080/13669 877.2011 .571773 
Mazur A (2004) True warnings and false alarms. Resources for the Future, Washington DC

Mazur A (2006) Risk perception and news coverage across nations. Risk Manag 8:149-174. https://doi.org/10.1057/palgrave. rm. 8250011

Neuendorf KA (2017) The content analysis guidebook, 2nd edn. Sage, Thousand Oaks

Nygrén NA, Kontio P, Lyytimäki J, Tapio P, Varho V (2015) Early adopters boosting the diffusion of sustainable small-scale energy solutions. Renew Sustain Energy Rev 46:79-87. https://doi. org/10.1016/j.rser.2015.02.031

Owens K (2017) Too much of a good thing? American childbirth, intentional ignorance, and the boundaries of responsible knowledge. Sci Technol Hum Values 42(5):848-871. https://doi. org/10.1177/0162243917697193

Peltola T (2011) Energy policy or forest policy or rural policy? Transition from fossil to bioenergy in Finnish local heating systems. In: Järvelä M, Juhola S (eds) Energy, policy, and the environment. Springer, New York, pp 155-171. https://doi. org/10.1007/978-1-4614-0350-0_9

Perl A, Howlett M, Ramesh M (2018) Policy-making and truthiness: can existing policy models cope with politicized evidence and willful ignorance in a "post-fact" world? Policy Sci 51(4):581600. https://doi.org/10.1007/s11077-018-9334-4

Pöykiö R, Watkins G, Dahl O (2018) Evaluation of the utilization potential of debarking residue based on the requirements of Finnish waste legislation. Clean Technol Environ Policy. https://doi. org/10.1007/s10098-018-1632-1

Proctor R, Schiebinger L (eds) (2008) Agnotology: the making and unmaking of ignorance. Stanford University Press, Stanford

Rayner S (2012) Uncomfortable knowledge: the social construction of ignorance in science and environmental policy discourses. Econ Soc 41(1):107-125. https://doi.org/10.1080/03085 147.2011.637335

Routa J, Kolström M, Sikanen L (2018) Dry matter losses and their economic significance in forest energy procurement. Int J For Engin 29(1):53-62. https://doi.org/10.1080/14942119.2018.14213 32

Schmidt A, Ivanova A, Schäfer MS (2013) Media attention for climate change around the world: a comparative analysis of newspaper coverage in 27 countries. Glob Environ Change 23(5):1233-1248. https://doi.org/10.1016/j.gloenvcha.2013.07.020

Schot J, Geels FW (2008) Strategic niche management and sustainable innovation journeys: theory, findings, research agenda, and policy. Technol Anal Strateg 20(5):537-554. https://doi. org/10.1080/09537320802292651

Schwarzkopf S (2018) Sacred excess: organizational ignorance in an age of toxic data. Organ Stud. https://doi.org/10.1177/0170840618 815527

SeAMK (2018) TUOHI-hankkeen tutkimus: Energiatehokkuus ja taloudellisuus paranevat polttamalla tuorepuuta. https://www. seamk.fi/tuohi-hankkeen-tutkimus-energiatehokkuus-ja-taloudelli suus-paranevat-polttamalla-tuorepuuta/. Accessed 18 Nov 2018

Skjølsvold TM (2012) Curb your enthusiasm: on media communication of bioenergy and the role of the news media in technology diffusion. Environ Commun 6(4):512-531. https://doi. org/10.1080/17524032.2012.705309

Smithson M (1989) Ignorance and uncertainty: emerging paradigms. Springer, New York

Soimakallio S (2017) Biomassan energiakäyttö: vaikutukset hiilinieluihin ja ilmastopäästöihin. In: Yrjö-Koskinen E (ed) Arktinen murros-Ilmastonmuutos ja luonnonvarojen käyttö pohjoisilla napa-alueilla. Into Kustannus, Helsinki, pp 91-124

Stocking SH, Holstein LW (1993) Constructing and reconstructing scientific ignorance: ignorance claims in science and journalism. Knowl Creat Diffus Util 15(2):186-210

TUOHI (2018) TUOHI-Tuoreen energiarangan hankintalogistiikan kehittäminen. University of Vaasa. http://www.uva.fi/fi/cooperatio n/projects/tuohi-tuoreen_energiarangan_hankintalogistiikan_kehit taminen/. Accessed 18 Nov 2018

VTT (2014) Puupolttoaineiden laatuohje. VTT-M-07608-13-päivitys 2014. Bioenergia ry \& Energiateollisuus ry \& Metsäteollisuus Ry. https://www.vtt.fi/inf/julkaisut/muut/2014/VTT-M-07608 -13_2014_\%20update.pdf Accessed 12 Feb 2019

Publisher's Note Springer Nature remains neutral with regard to jurisdictional claims in published maps and institutional affiliations. 